\title{
EXPERIENCE-BASED LEARNING IN THE CONTEXT OF ETHICAL EDUCATION
}

\section{[ZAZITKOVE UCENIE V KONTEXTE ETICKEJ VYCHOVY]}

\author{
Vladimir Fedorko - Martin Dzurilla
}

doi: 10.18355/PG.2018.7.1.12

\begin{abstract}
In this paper, we analyze experience-based learning in the subject of ethical education as one of the most effective methods that help students keep permanently personally realized and inner experiences - I can utilize what I experience. We point out to experience mainly as the means of the objective achievement, it is not dominant, and we focus on the Kolb' cycle of experience identification that has an unsubstitutable position in ethical education.
\end{abstract}

\section{Key words}

experience-based learning, ethical education

\section{Anotácia}

$\mathrm{V}$ našom príspevku analyzujeme zážitkové učenie $\mathrm{v}$ rámci predmetu etická výchova, ako jednu z najefektívnejších metód, ktorá dokáže v žiakovi trvalo udržat' sebe uskutočnené prežívanie a zvnútornené skúsenosti - čo zažijem, to dokážem použit'. Poukážeme, že zážitok je hlavne prostriedok k dosiahnutiu ciel'a, nie je dominantný a svoju pozornost' upriamime aj na Kolbov cyklus skúsenostného učenia, ktorý má nenahraditel'né miesto $\mathrm{v}$ etickej výchove.

\section{Kl'účové slová}

zážitkové učenie, etická výchova

\section{Úvod}

„Povedz mi niečo a ja to zabudnem. Ukáž mi niečo a ja si to zapamätám. Dovol' mi, aby som si to vyskúšal na vlastnej koži a ja to budem ovládat'. Dovol' mi, aby som to prežil a ja to budem cítit' a chápat'. Ak sa má stat' človek človekom, musí sa vzdelávat'. J. A. Komenský

Vychádzajúc zo súčasnej praxe a postavením niektorých predmetov $\mathrm{V}$ školstve vieme, že žiaci na základných školách nemajú stále rešpekt pred neklasifikovanými predmetmi, akým je napríklad etická výchova. Daný učitel' musí preto vynaložit' všetko svoje pedagogické majstrovstvo, aby žiakov motivoval k spolupráci v rámci predmetu.

\section{Zážitková pedagogika}

Zážitková pedagogika patrí k novším pedagogickým smerom. Zážitková pedagogika sa snaží pomôct' žiakom prekonat' strach zo školy, nechut' k učeniu a nadobudnút' radost'. Na základe zážitku a skúsenosti vedie žiakov $\mathrm{k}$ 
aktívnemu prístupu k získavaniu vedomostí. Okrem získania informácií napomáha žiakom vyjadrovat' vlastné myšlienky, emócie, rešpektovat' názory iných, rozvíjat' empatiu, tvorivost', schopnost' spolupráce a podobne. Zážitková pedagogika patrí doteraz ešte $\mathrm{k}$ nezaradeným a viac menej neakceptovatel'ným pedagogickým smerom a hl'adá svoje špecifiká, systematiku a hlavne miesto $\mathrm{v}$ súbore pedagogických disciplín. „Napriek tomu sa $v$ súčasnosti $v$ rôznych publikáciách objavujú termíny ako výchova zážitkom, zážitková výchova, zážitkové vyučovanie. Tieto pojmy súvisia pravdepodobne s prekladmi pedagogických smerov zo zahraničia ako napr. adventure education, enviromental education a.i." (Jirasek, 2008). Vymedzenie pojmov zážitková pedagogika a zážitkové učenie nie je teda jednoduchou záležitost'ou a nesie so sebou vel'a nejasností. Z anglického originálu experiental education sa tento pojem do slovenčiny prekladá ako skúsenostné alebo zážitkové vyučovanie, prípadne aktívne učenie. Na Slovensku tak vznikajú rôzne alternatívne pedagogické prúdy. Tieto prúdy však so sebou tak úzko súvisia, že je niekedy t'ažké určit' o aký smer vzdelávania ide. Niekedy sa stáva zážitkové vyučovanie súčast'ou iného smeru ako napríklad aktívne učenie. „V terminológii Leea je aktívne učenie charakterizované aj ako zážitkové, teda založené na zážitku a skúsenosti, charakterizované priamym kontaktom s vecami, l'ud'mi, prírodou, obsahuje uvedomovanie si vlastného preživania a jeho reflexiu“ (Oravcova, 2003, s. 16). Metódy a princípy zážitkovej pedagogiky majú teda bližšie $\mathrm{k}$ alternatívnym smerom, ktoré sa rôznym spôsobom snažia o výchovu a vzdelávanie žiakov. Príkladom môže byt' Montessoriová pedagogika kladúca tiež dôraz na aktivitu žiaka a uplatňujúca heslo: Pomôž mi, aby som to dokázal sám. Frenetovská pedagogika zase využíva slobodné vyjadrovanie citov a Pragmatická pedagogika má založené formy učenia na skúsenosti, čo je vel'mi podobné zážitkovej pedagogike.

\section{Zážitkové učenie v etickej výchove}

Zážitkové vyučovanie, učenie ako už konkrétny spôsob edukácie sa snaží prostredníctvom zážitku a skúsenosti pomôct' žiakovi získat' vedomosti, schopnosti a zručnosti tak, aby si ich osvojil na celý život, čo v rámci etickej výchovy je najefektívnejšia metóda. Zážitkové učenie sa však nesústred'uje len na vyvolanie zážitku, to by bolo pre žiaka vel'mi málo. Zameriava sa predovšetkým aj na jeho spracovanie. Vyvolanie zážitku je súčast'ou štvorčast'ového cyklu vyučovania, do ktorého sa môže vstúpit' v ktorejkol'vek fáze. Zážitkové učenie aktivizuje žiaka počas celej vyučovacej hodiny, prirodzene ho motivuje $\mathrm{k}$ učeniu a zároveň rozvíja emocionálnu stránku jeho osobnosti, čo spín̆a požiadavky špecifického predmetu ako je etická výchova (Tkáč 2014). Zážitkové učenie spája v sebe zážitkové a skúsenostné metódy, je založené na osobnej aktivite človeka a dominantným je zážitok, ktorý vzniká pri aktívnom riešení najrozličnejších úloh, reálnych aj modelových. Následnou reflexiou usmerňovanou učitel'om etickej výchovy sa žiakov zážitok premení do podoby skúsenosti, ktorá sa dá využit' v praxi, reálnom živote žiaka. Doviest' zážitkovú vyučovaciu hodinu etickej výchovy do úspešného konca však nie je l'ahké. Vyučovacia hodina tohto typu v sebe zahŕňa určité špecifické kritériá (Denkova, 2013). Ciele etickej výchovy si 
vyžadujú používanie metód zážitkového vyučovania (Oravcova, 2004). Nemôžeme ich však uskutočňovat' bez pozitívnej a priaznivej atmosféry $\mathrm{v}$ triede. Učitelia etickej výchovy patria k popredným pedagógom, ktorí na školách používajú metódy zážitkového vyučovania (Oravcova, 2004). Podl’a ich skúseností žiaci vnímajú zážitkové metódy pozitívne, no nie je jednoduché tieto metódy používat' zvlášt' $\mathrm{v}$ neklasifikovanom predmete ako etická výchova. Pri zážitkovom vyučovaní sa mení štruktúra, proces či dianie na vyučovacej hodine (Oravcova, 2004). Tým, že vyučujúci zapája na hodine všetkých žiakov, niektorí sa môžu skrývat' za práce iných a nemusia spolupracovat'. Učitel' preto musí nájst' vhodný spôsob, aby žiakov zaujal a dal im priestor na spoluprácu. Ak by sme mali charakterizovat' zážitkové učenie v etickej výchove bolo by nasledovné:

1. participatívne učenie (aktívni aj učitelia aj žiaci, žiaci $\rightarrow$ iniciatívne a tvorivo sa zúčastňujú na prijímaní a spracovávaní poznatkov $\rightarrow$ stimulácia vlastných procesov myslenia a vytvárania nových nápadov a perspektív),

2. kooperativne a interaktívne učenie (vytvára pozitívne medziludské vzt’ahy, znižuje apatiu a stavy úzkosti, podnecuje efektívnu otvorenú a presnú komunikáciu, spolupráca a prijímanie zodpovednosti),

3. uvedomovanie si vlastných hodnôt, postojov alebo citov (zmena porozumenia seba, iných l'udí, prírody, okolitého sveta, zmena postojov i správania...),

4. kreatívne učenie (rozvoj vyšších kognitívnych spôsobilostí, rozvoj divergentného myslenia, rozvoj riešenia konfliktov, tvorba perspektív, spájat' racionálne a intuitívne uvažovanie, myslenie $\mathrm{v}$ pojmoch $\mathrm{i}$ obrazoch $\rightarrow$ výchova $\mathrm{k}$ tvorivosti, $\mathrm{k}$ zdravému sebavedomiu, samostatnosti a aktivite),

5. podporuje pozitívne hodnotenie seba $i$ iných (vytvára pozitívnu atmosféru bezpečia a lásky),

6. aktívne učenie,

7. učenie založené na zážitku a skúsenosti (priama interakcia s vecami, prírodou, l'ud'mi prináša zmeny v správaní a v interpretácii prežitého $\rightarrow$ viest' $\mathrm{k}$ schopnosti učit' sa),

8. od učitel'a vyžaduje sociálno-psychologické zručnosti (forma sociálnopsychologických výcvikov $\rightarrow$ učitel': vysoké sociálne cítenie, empatia, tvorivost').

Pre úspešné zvládnutie zážitkovej vyučovacej hodiny musí učitel' dodržiavat' tieto kritériá:

Vek žiakov

Učitel' by mal používat' vo vyučovacom procese také aktivity, ktoré sú primerané vývinovému obdobiu žiakov. Starší žiaci neradi spolupracujú pri modelových situáciách, ked' majú hrat' divadielko. Radšej ich zaujímajú riešenia nastolených problémov formou diskusie. Mladší žiaci sa radšej zapájajú do hier a svoje názory a pocity zverejňujú ochotnejšie.

Skupinová klíma

Učitel' by mal akceptovat' rôzne vyjadrenia a názory žiakov, aby celková atmosféra $\mathrm{v}$ triede nebola napätá a aby sa vytvoril pocit dôvery a rešpektu. Zároveň by mal učitel' zohl'adňovat' fakt, ked' žiak z osobných dôvodov 
odmieta zaujat' stanovisko a vyjadrit' postoj $\mathrm{k}$ nastolenému problému na vyučovacej hodine. Atmosféra v triede by mala byt' dostatočne bezpečná, aby sa prípadné dôvernosti nezverejňovali osobám mimo skupiny.

\section{Nadhl'ad učitel'a}

Učitel' by nemal vstupovat' do riešenia problémov $\mathrm{v}$ skupine, aby neobmedzoval slobodné vyjadrenia postojov žiakov. Nenásilnou formou by mal iba poukazovat' na to, čo sa hodnotí ako správne. Mal by sa vystríhat' toho, aby do vyučovacej hodiny nevnášal nepokoj alebo nervozitu $\mathrm{Z}$ vlastných osobných problémov. Napokon, učitel' by nemal presadzovat' pred žiakmi názor za každú cenu, ktorý považuje za správny.

Disciplina žiakov

Úlohou vyučujúceho je vynaložit' všetko úsilie a prostriedky na to, aby disciplína $\mathrm{v}$ triede bola prijatel'ná a nerušila celkový priebeh vyučovania. Samopašnost' žiakov pri riešení chúlostivých a citlivých tém nebýva na mieste. Tak isto hlučné, ba až vulgárne, správanie žiakov môže pokazit' celkový dojem z vyučovacej hodiny.

Autorita učitel'a

Niektorí učitelia etickej výchovy si žiakov pripúšt’ajú až príliš blízko. Myslia si, že vytvoria takýmto spôsobom v kolektíve priatel'skú atmosféru. Poslanie učitel'a by však nikdy nemalo smerovat' až tak d'aleko, aby si so žiakmi tykal. Pri tykaní učitel' síce stráca nadradenost', ktorú na hodine etickej výchovy nechce dosiahnut', ale žiaci túto skutočnost' vnímajú inak. Neberú učitel'a ako rovnocenného partnera, správajú sa k nemu skôr neúctivo. Optimálne by bolo dosiahnut' stav, kedy by učitel' zostal autoritou, ktorú by žiaci rešpektovali, no zároveň by vystupoval ako partner, ktorý je ochotný pomôct' v každej situácii, ak o to žiak požiada.

Auto-reflexia žiakov

Spätná väzba je neodmyslitel'nou súčast'ou vyučovacej hodiny. Každá vyučovacia jednotka začína nastoleným ciel'om. Etická výchova je vyučovací predmet o hodnotách. Stratila by zmysel, keby nestála na pilieroch sebareflexie. Úlohou učitel'a je doviest' vyučovaciu hodinu do konca. Počas vyučovacej hodiny dáva žiakom priestor na vyjadrenie svojich hodnôt či postojov prostredníctvom zážitku, ktorý prežili počas vyučovacej hodiny, ked’ sa na nastolený problém dokázali pozriet' vlastnými očami. Sebareflexia začína slovíčkom ,ja“. Vyjadruje sa v prvej osobe slovami: ja si myslím, že..., ja to chápem tak..., ja som to cítil ako...Na zážitkovej vyučovacej hodine učitel' nastavuje žiakom zrkadlo a oni prostredníctvom prežitého nazerajú do svojho vnútra (Denkova, 2013, s. 43 - 44).

\section{Kolb a teória l'udského učenia sa}

Kolb v roku 1984 publikoval knihu Experiential Learning: Experience As The Source Of Learning And Development, v ktorej rozvinul teóriu l'udského učenia sa. Podl'a tohto modelu, učenie je najlepšie ako koncept procesu, nemalo by sa súdit' podl'a výsledkov. Učenie je nepretržitý proces založený na skúsenosti a je to proces adaptácie. Zahŕňa prenos informácií medzi osobou a prostredím a vyžaduje riešenie konfliktov medzi diskutujúcimi oproti spôsobu adaptácie. Učenie je proces vytvárajúci znalost', ktorá je výsledkom transakcie medzi sociálnou znalost'ou a osobnou znalost'ou. Kolb 
taktiež definoval tri štádiá l'udského vývinu a tvrdí, že schopnost' l'udí učit' sa, podl'a ním navrhnutého cyklu učenia, sa zlepšuje počas dospievania. Prvým štádiom je získavanie. Je to obodobie od narodenia sa do veku predškoláka, kedy sa vyvíjajú základné schopnosti a kongnitívne štruktúry. Druhým štádiom je špecializácia, kam patria roky človeka strávené v škole, prvé pracovné skúsenosti a skorá dospelost'. V tomto období sa vyvíja špecializovaný cyklus učenia, tvorený socilizáciou, vzdelávaním a organizáciou. Tretie štádium je integrácia, ktorá začína po druhom štádiu. V integrácii nedominuje vzdelávací štýl $\mathrm{v}$ osobnom ani $\mathrm{v}$ pracovnom živote. Učebný štýl je produktom dvoch volieb, ktoré robíme alebo preferujeme, a ktoré si navzájom odporujú. Konkrétny zážitok (CE), kedy sa človek potrebuje chytit' konkrétnej veci verzus abstraktný koncept (AC), kedy sa človek snaží veci analyzovat' a mysliet' logicky. Druhá vol'ba nastáva pri spracúvaní informácií. Prvý typ l'udí potrebuje experimentovat' s vecou (AE) a druhý typ l'udí veci reflektívne pozoruje (RO), počúva, hovorí o nich a hodnotí. Kombináciou týchto dvoch spôsobov Kolb vytvoril model, na základe ktorého l'udí zarad'uje do jedného zo 4 spôsobov prijímania a spracovávania informácií.

Typológia učiacich sa v Kolbovej teórii

Novátori-dominuje preživanie

Je to konkrétny a reflektívny učebný štýl. Patria sem l'udia, ktorí kombinujú cítenie (CE) a reflektívne pozorovanie (RO). Vyhovuje im prijímanie informácií v konkrétnej podobe a spracúvajú ich pomalšie. Sú schopní pozriet' sa na veci z inej perspektívy, sú citliví a radšej sa pozerajú ako konajú. Použivajú predstavivost' na riešenie problémov. Radi riešia problémy a otázky, učia sa počúvaním a vzájomnou výmenou názorov. Sú kreatívni a najlepšie výkony podávajú v situáciach, ktoré si vyžadujú tvorenie nápadov. Myslenie a poznávanie sa u nich rozvíja viacerými smermi a preto mávajú vel'a nápadov. Zaujímajú sa o l'udí, majú vel'kú predstavivost' a sú emociálne založení. Vel'mi často majú sklony k umeniu. Volia si štúdium humanitných a umeleckých študijných odborov. Vyhovuje im tímová práca a nevadí im dostávat' spätnú väzbu. Ich ciel'om je byt' zapojený do dôležitých vecí. Hladajú význam a motivuje ich zvedavost'.

Analytici- dominuje vnímanie

Je to abstraktný a reflektívny štýl. Patria sem l'udia, ktorí využívajú abstraktný koncept (AC) a reflektívne pozorovanie (RO). Vyhovuje im logický prístup, myšlienky a logické koncepty sú doležitejšie než l’udia. Vyžadujú vysvetlenie namiesto praktickej skúsenosti. Vynikajú v pochopení informácií a organizovaní ich do logického formátu. Učia sa premýšl'aním a detaily sú pre nich dôležité. Nezaujímajú ich až tak l'udia, ako abstraktné koncepty. Ovel'a viac ich prit’ahujú logicky znejúce teórie, ako praktické prístupy. Často pracujú ako vedci. V procese učenia sa im vyhovujú čítania, prednášky, analytické modely. Potrebujú dostatok času na premýšl'anie. Vyhl'adávajú osobné uspokojenie a intelektuálne poznanie. Ich ciel'om je byt' uznávaný za vysokú intelektuálnu úroveň a racionalitu. Vyhl'adávajú názory expertov, motivuje ich dokonalost', ale sú príliš kritickí a zabúdajú na praktické aplikácie.

\section{Praktici-dominuje myslenie}


Je to abstraktný a aktívny učebný štýl, tvorený kombináciou abstraktného konceptu(AC) a experimentovaním s vecami(AE). L'udia tohto typu vnímajú informácie $\mathrm{v}$ abstraktnej podobe a spracúvajú ich aktívne. Dokážu riešit' problémy a svoje zistenia použivajú na riešenie praktických problémov. Problémy riešia hl'adaním odpovedí na otázky. Majú radi technické úlohy, neprejavujú záujem o l'udí a medzil'udské problémy. L'udia tohto typu radi experimentujú $\mathrm{s}$ novými nápadmi a pracujú s praktickými aplikáciami. Zručnosti si chcú osvojit' sami a fakty získavajú sami. Vel'mi rýchlo dokážu dospiet' $\mathrm{k}$ správnej odpovedi. Často si volia štúdium aplikovaných prírodovedných študijných odborov. Chcú byt' považovaní za výkonných, no všetko spochybňujú a netolerujú nejasné a komplikované nápady. Motivujú ich problémy, vyhl'adávajú bezpečnost' a istotu. Najlepšie sa učí kladením otázok, psychomotorickými skúsenost’ami, testovaním hypotéz, metódou rozhovoru. Ich slabou stránkou je to, že riešia aj nesprávne definované problémy.

\section{Dynamickížiaci- dominuje konanie}

Je to konkrétny a aktívny učebný štýl. Tvorí ho kombinácia cítenia (CE) a experimentovania s vecami (AE). Ludia tohto typu sa viac spoliehajú na intuíciu ako na logiku. Použivajú analýzy iných l’udí a sami preferujú praktický prístup. Nechajú sa zlákat' novými výzvami a experimentmi, často sa spoliehajú na druhých, než by radšej spravili vlastnú analýzu. Spájajú poznatky a prax, učia sa metódou pokus-omyl. Majú radi zmeny a radi riskujú. Vyhovuje im práca $\mathrm{v}$ tíme. Radi si dávajú osobné ciele. Často vykonávajú technické povolania a povolania $\mathrm{v}$ oblasti obchodu a služieb. Ich ciel’om je vytvorit' funkčné veci, motivuje ich výsledok práce a konečný produkt. Často bývajú extroverti a sú vel'mi netrpezliví. Hladajú skryté možnosti. Preberajú úlohu vodcu a chcú problémy riešit', ale často robia činnosti, ktoré vôbec nie sú potrebné alebo vyvodzujú závery bez uvažovania. Niektorí l'udia preferujú jeden štýl, a s druhým sa cítia vyslovene nepohodlne. U väššiny sa však učebné štýly prelínajú, a preto nie je vždy l'ahké určit, ktorý je ten dominujúci.

Teória zároveň vysvetluje aj cyklus experimentálneho učenia sa, ktorý sa vzt’ahuje na všetkých l'udí. Cyklus pozostáva zo všetkých 4 typov a môže začat' v ktoromkol'vek bode. 1. Konkrétna skúsenost'. 2. Reflexia, uvažovanie nad prežitou skúsenostou. 3. Vytváranie abstraktných konceptov a predstáv. 4. Experimentovanie so závermi, tvorba nových konceptov. Kolbova teória sa prelína s teóriami osobností, napríklad MBTI typológiou. Kolbovou teóriu sa inšpirovali aj Honey a Mumford, ktorí vytvorili vel'mi podobnú teóriu. V tejto teórii sú tiež 4 typy l’udí a korešponduje s Kolbovým cyklom učenia sa.

$\begin{array}{lll}\text { Aktivisti } & - & \text { 1. fáza } \\ \text { Reflektori } & - & \text { 2. fáza } \\ \text { Teoretici } & - & \text { 3. fáza } \\ \text { Pragmatici } & - & \text { 4. fáza }\end{array}$




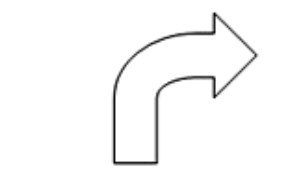

APLIKÁCIA

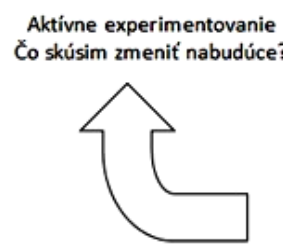

AKCIA

Učiter niečo skúsi

ABSTRAKCIA

Porozumenie

súvislostiam

Prečo sa to udialo?

Čo sa z toho učitel"

dozvedel (o sebe,

o žiakoch, o procese

vzdelávania)?

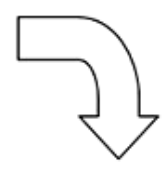

REFLEXIA

Spolu s mentorom zreflektuje Co sa dialo? Ako to išlo? Ako sa pri tom cítil?

\section{Obrázok 1 Kolbov cyklus}

\section{Záver}

Z uvedeného tiež vyplýva, že vyučovanie etickej výchovy nie je jednoduchou záležitost'ou a skutočne len tí učitelia, ktorí tento predmet vyučujú dobre poznajú jeho náročnost'. Je smutné, že často až vlastná skúsenost'

132 s vyučovaním tohto predmetu presvedčí pedagógov, že učit' dobre etickú výchovu nie je l'ahké a radostné a že profesionálne zvládnutie tohto predmetu je vysoko náročné na odborné, pedagogické, ale najmä l'udské kvality pedagóga (Oravcova, 2004).

\section{Bibliographic references}

HERINKOVA, E. 2016. Kolbova teoria ucenia sa. In: Eduworld : Bratislava. [cit. 2017-10-31]. Available online: https://eduworld.sk/cd/eliskaherinkova/3194/kolbova-teoria-ucenia-sa

JIRASEK, I. 2004. Vymezeni pojmu zazitkova pedagogika. In: Gymnasion, 2004, c.1, s. 6-16.

DENKOVA, J. 2013. Zazitkove vyucovanie v praxi ucitela. In: PRIMAS: Objavne vyucovanie matematiky a prirodovednych predmetov. Zbornik z odbornej konferencie. PRIRODOVEDEC c. 550 : Nitra. ISBN 978-80-5580442-2.

ORAVCOVA, J. 2003. Aktivne ucenie a jeho suvislosti so stylmi ucenia a osobitnymi vlastnostami vysokoskolskych studentov. Habilitacna prcca. Univerzita Mateja Bela : Banska Bystrica.

ORAVCOVA, J. 2004. Pravidla prace pri aplikacii aktivneho ucenia (zazitkoveho) na hodinach etickej vychovy. Fakulta humanitnych vied UMB: Banská Bystrica. Pedagogické rozhlady 4/2004, s. 4., [cit. 2017-10-27]. Available online: http://www.rozhlady.pedagog.sk/cisla/pr4-2004.pdf PETLAK, E. 2004. Vseobecna didaktika. 2. vyd. Bratislava : Iris. ISBN 8089018-64-5. 
PRUCHA, J. - WALTEROVA, E. - MARES, J. 2008. Pedagogicky slovnik. Praha : Portal. ISBN 978-80-736-7416-8.

TKAC, K. 2014. Zazitkove vyucovanie v edukacnom procese. SOS Lipany : Lipany. Skola buducich desatroci. ITMS kod projektu 26130130100.

Mgr. Vladimír Fedorko, PhD.

Department of Pre-school and Elementary Pedagogy and Psychology Faculty of Education

University Prešov in Prešove, Ul. 17. novembra č. 15

08001 Prešov

Slovakia

vladimir.fedorko@unipo.sk

Mgr. Martin Dzurilla, PhD.

Department of Music and Art Education

Faculty of Education

University Prešov in Prešove,

Ul. 17. novembra č. 15

08001 Prešov

Slovakia

martin.dzurilla@unipo.sk 